to grapple. Moreover, it is also of concern that the decision to extend the initiative has been taken before the Department of Health's evaluation of it - by a team at Brunel University - has been completed. The final report is not due until towards the end of 1989.

\section{Access to health care}

While competition may yield efficiency gains there is always a danger that without safeguards these will be achieved at the expense of a loss of equity.

Services offering clear revenue earning potential will become more attractive. Many health promotion and screening services-primarily aimed at the affluent, worried well-are likely to fall into this category. Similarly, it will be easy to draw up service contracts for well defined, short stay, minor elective surgery. Providing long term care for the mentally ill and handicapped, the chronically sick, or for elderly people suffering from dementia may hold less attraction as a source of revenue.
Access to services will also be influenced by the location of services resulting from the competitive process. If competition leads to greater specialisation and the concentration of services at fewer sites there will be greater need for some patients to travel further for treatment. This might penalise less mobile people and their families. Continuity of care after hospital discharge for those patients treated outside their home districts may also be a problem. Liaison between hospitals and local general practitioners, social service departments, and community services is already a cause of concern. Treatment at a distance might exacerbate these difficulties.

1 Secretaries of State for Health, Wales, Northern Ireland, and Scotland. Workin for patients. London: HMSO, 1989. (Cmnd 555.)

Enthoven AC. Reflections on the management of the National Health Service. London: Nuffield Provincial Hospitals Trust, 1985.

3 McGuire A, Henderson J, Mooney G. The economics of health care. London Routledge and Kegan Paul, 1988.

4 Pollitt C, Harrison S, Hunter D, Marnoch G. The reluctant managers: clinicians and budgets in the NHS. Finance Accountability and Managemen 1988;213:33.

\title{
The illnesses of Elizabeth Barrett Browning
}

\author{
D A B Young
}

Although Elizabeth Barrett Browning, 1806-61, was famous in her own day as a poet, she is now remembered almost exclusively for her romance with Robert Browning. Their love story became known throughout the world in the 1930s in the celebrated film of Rudolph Besier's play The Barretts of Wimpole Street. In this Elizabeth, a fragile, chronic invalid, confined to her bedroom for eight years with a respiratory illness, defied both her condition and her father's tyrannical selfishness to elope with and marry a little known poet of limited means.

The romance of the elopement, however, depended entirely on the invalidism, for Miss Barrett was 40 years of age, had a private fortune, albeit a modest one, and was a successful writer. That in the remaining 15 years of her life she bore a child, had four miscarriages, travelled widely, and led a much more active and adventurous existence than she had done before, must lead to grave doubts about the genuineness of her illness. The traditional diagnosis of tuberculosis, which was not countenanced by her doctors, has little to support it. ${ }^{1}$ Consequently many biographers have suggested one or more of the following as the explanation of her invalidism: hypochondria, frank malingering, opium addiction, and mental illness.

Before her marriage Elizabeth Barrett had two major periods of illness - 1821-2 and 1837-46. Interestingly, all her biographers have linked the two illnesses, even if only to suggest that the second exploited the techniques of hysterical self deception perfected in the first. As the illnesses were quite different and lacked any exact diagnoses such linkage without justification is unwarranted. But the real difficulty about Miss Barrett's second illness is that for a non-tubercular respiratory condition to have so dominated a young person's life for eight years there must have been an additional disablement. I believe that the first illness holds the key to the problem.

Our information regarding the first illness has two different components, which have been difficult to reconcile-namely, information about an accident and about a sickness. The former concerns an accident that Elizabeth had while saddling her pony. According to her son Pen Browning, the spinal injury, not suspected at first, was caused by a strain while tightening the pony's girths. This was essentially corroborated by her friend Lady Ritchie. ${ }^{2}$

The second component is two letters from doctors regarding a sickness rather than an injury. ${ }^{3}$ One letter from a Dr Carden, dated 8 May 1821, states that the symptoms of the "harassing malady" were considerably mitigated, and he recommended cold showers, more quinine, and as much exercise in the open air as possible ("and if the rides could be varied the advantage would be greater"). His letter also indicates that at least one other of the Barrett children was also affected ("a little more to the eldest and rather less to the youngest, of the volatile tincture of valerian"). A second and much more detailed letter from a Dr Coker, dated 24 June 1821, describes the "history and present symptoms" of the case:

It began with pain in the head, which continued at intervals for seven weeks - the pain then attacked various parts of the body, for a considerable period, and for the last month it has permanently seated itself on the right side, that is about the centre of the angle formed by the greatest projection of the ribs, the umbilicus and the anterior superior spinous process of the ischium [? ilium]. The pain commences here, is carried to the corresponding region of the back, up the side to the point of the right shoulder and down the arm. The suffering is agony-the paroxysms continue from a quarter of an hour upwards-accompanied by convulsive twitches of the muscles, in which the diaphragm is particularly concerned.

\section{Three attacks a day}

Although Miss Barrett remained conscious throughout, at the close of each attack, of which there were generally three a day (none at night), she was confused. The pain and weakness in the back prevented her sitting up without support. She was unable to lie on her right side, had the sensation of her side being swollen, and complained in the mornings that it felt as if a cord had been tied around her stomach. It seems that though opium had at first relieved the spasms it soon ceased to be effective.

Dr Coker could detect nothing obviously wrong

9ND. 
with the spine, but the case strikingly resembled one that he had seen some years before of a young woman, which ended "in decided affection of the spine." She had had the same kind of spasms as Miss Barrett, though it was the left side that was affected. Dr Coker added that neither he nor the other attending doctors had had any reason "to imagine there was disease of the spine"; yet four weeks later when that young woman had made some improvement he had no doubt that the vertebral column was then affected. Despite the spinal "affection," the young woman eventually married and bore three children. "I would recommend, generally, the treating of Miss Barrett's case as for diseased spine." Dr Coker also noted that Miss Barrett's two sisters, Henrietta and Arabella (then aged 12 and 7 respectively):

Had some time since the same kind of pain, or nearly so which occupied the second stage of this malady. They were all suffering at the same time, which created a suspicion that they had taken something deleterious - They both however soon recovered, without much, if any medical treatment.

Finally, in an undated letter Elizabeth writes: "Dr Baron comes to examine my back accurately and with particular care. ... I trust in God it will prove not to be the spine."

The verdict must have been that it was the spine, for in a letter to Miss Mitford in August 1837 before her second illness, referring to her habit of reclining on a sofa rather than sitting in a chair, she writes: "I used once to suffer from a feebleness in the spine, and even now it is exceedingly fatiguing to me, to sit bolt upright without the mediation of the back of a chair, for any length of time." In another letter to Miss Mitford (June 1841) - in response to hearing that her friend, while viewing a house under construction, had fallen through a floor and among other injuries had severely bruised her spine-Elizabeth shows an alertness to a problem that usually comes only from personal experience:

How is the spine, the jarring of which I liked least of all to hear of? Do you lie down rightly and prudently and remain quiet in every way until the system recovers itself? Because, indeed you should ... you must.... Tell me ... whether the swelling upon the spine has passed away."

In a letter to her brother George written immediately before leaving for France after her secret marriage she writes:

That, as to the question of my health, he $[R B]$ had been under the impression, when he first declared his attachment to me, that I was suffering from an incurable injury to the spine that would prevent my ever standing up before his eyes. ${ }^{3}$

Elizabeth would never have written that in a letter substantiating Browning's love for her and justifying her own conduct if there was no basis whatsoever for such an impression regarding her spine.

And Browning could have obtained the basis for that impression only from his friend John Kenyon, who was also a close friend and relative of Elizabeth and would in turn have acquired the information from either her or her immediate family. Browning's exaggeration of the disability was natural when he saw her confined perpetually to a sofa in her room. That the family acknowledged her spinal injury is evident from an article written by Elizabeth's niece, Arabella Moulton-Barrett, as late as 1938 in a newspaper in Jamaica. ${ }^{6}$ Angered by the characterisation of her grandfather in the film The Barretts of Wimpole Street, she defended his reputation by savaging that of her aunt and attributed Elizabeth's ill health entirely to an injury to her spine sustained in an accident with her pony, aggravated by deliberate malingering. Arabella was the daughter of Elizabeth's brother Charles "Stormie" (1814-1905) and must have got her information from her father. He went out to manage the family

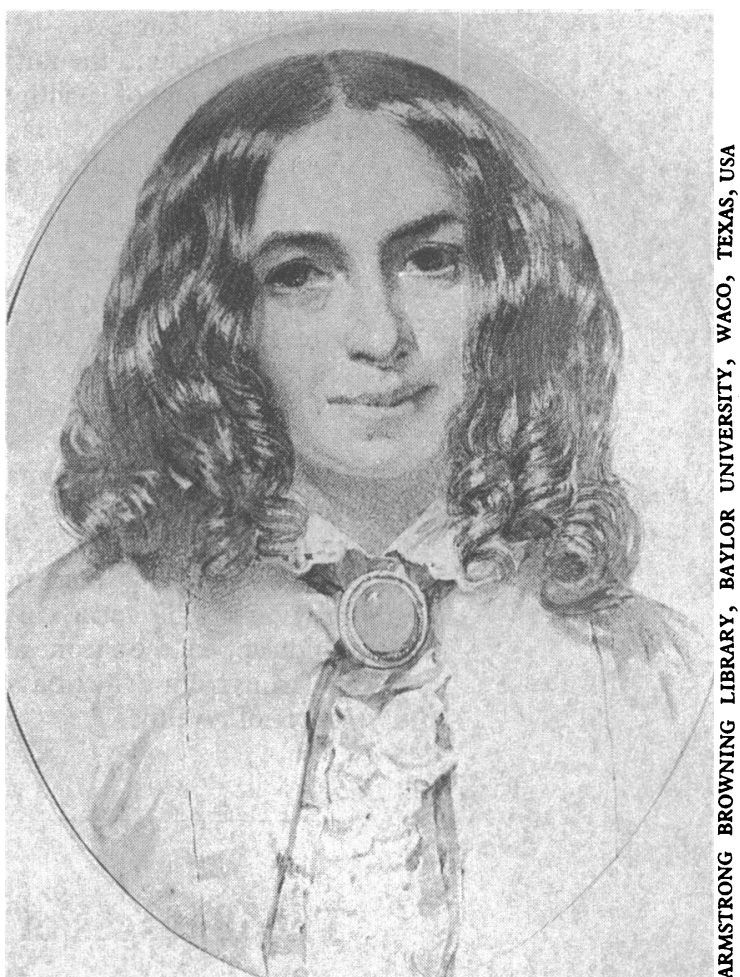

FIG 1-Elizabeth Barrett Browning by E F Bridell, Rome 1858

estates in Jamaica after his father's death in 1857 , married there in 1865, and never returned to live in England again.

The evidence for a spinal injury seems too substantial, therefore, to be rejected as apocryphal, as some have done ${ }^{4}$ solely on the grounds that it cannot be reconciled with the sickness described by Dr Coker. Indeed, from the evidence available I believe a reasonable hypothesis can now be constructed that accounts for Miss Barrett's illnesses.

\section{Poliomyelitis}

The simultaneous occurrence of headaches and malaise in the three Barrett daughters suggests an infection. The prolonging of the pains and their presence in various parts of the body as a secondary stage and, finally, in Elizabeth's case, the extremely painful paroxysms and muscle twitching leading eventually to the appearance of a spinal "injury," suggests poliomyelitis, resulting in paralytic scoliosis for the unfortunate eldest sister. The description of the earlier stage of the illness supplied by Dr Coker and the implications of Dr Carden's remarks together resemble the clinical description of non-paralytic poliomyelitis: a prodromal phase of milder symptoms followed by the major illness (Coker's second stage?) with the severer symptoms of malaise, fever, generalised headache, stiff neck, and back and deep muscle pains. The major discrepancy would be Dr Coker's "seven weeks"; but since he was depending on the information of others, I wonder whether this should not be "seven days." The painful stage of the malady may certainly last some weeks and three weeks' bedrest is recommended even in the mildest cases to allow affected muscles to regain their function. It seems from Dr Carden's letter that Elizabeth was encouraged to exercise far too early and, in particular, to go riding. As overstretching affected muscles may result in deformities from contracture this was probably the nature of the accident that occurred when she was tightening the pony's girths. But the affected muscles might never have recovered their function and scoliosis would have been inevitable. 
Such was the seriousness of her condition that in July 1821 Elizabeth was moved to Gloucester under the care of a Dr Nuttall, the addressee of Dr Coker's letter. She remained there, bedridden, for a year until, presumably, the severe muscular paroxysms and convulsions had ceased. But it was only after another year at home that she even partially recovered her health. It may even have been two years, for in a letter she writes: "When I was ill, my Father and Mother, during two years, scarcely ever left me to go anywhere ... tho' I was in immediate danger for only a few months."

Although for half the patients the onset of the scoliosis is within one year of the infection, for some it may be longer than two years, a time course that reflects the cause of the scoliosis - namely, the failure of growth in the unopposed, stronger muscles to match the continuing skeletal growth. Elizabeth's letter containing the reference to Dr Baron's examination of her spine probably dates therefore from 1823 or even 1824 . Little wonder that there was confusion about her first illness, for the delay between the infection and an obvious development of scoliosis may be so long that even today the primary illness may not be recognised.

The site of the initial pain suggests the subsequent development of at least a lumbar or thoracolumbar curve convex to the left. Hence you might expect a dropping of the left shoulder and a prominence of the right hip. Most portraits of Mrs Browning show her half front, but one by E F Bridell shows her full face and the difference in the level of the shoulders is marked, the left being dropped (fig 1). The same difference has been reproduced in the posthumous bust of her by the Brownings' good friend W W Story, based it would seem on Bridell's portrait. Of course, Mrs Browning would have disguised her problem as well as she could. One way to lessen the difference in the levels of her shoulders was to wear her hair long about her face, which works effectively (fig 2), but was noticed as an old fashioned and unflattering style. As regards a prominent hip, although there is no direct evidence, it is noteworthy that she wore unfashionable styles that would have the effect of disguising any such anomaly. Thus she was remembered by Lady Ritchie as "dressed in soft falling flounces of black silk." Three years earlier in 1851 Mrs Andrew Crosse was distinctly critical of her style of dress: "Her slight pretty figure was rather disguised than set off by garments that fell lopping round her." But perhaps this taste for loose hanging fashions was a disguise for more than a prominent hip.

A spinal curvature of this form developing in an adolescent girl would be most frequently of the idiopathic type, but it would cause neither the prolonged muscular paroxysms nor the serious respiratory handicap. But the average prognosis of a paralytic curve, on the other hand, is much more serious, having much longer curves and, more importantly, including widespread atrophy of muscle fibres of the trunk. In particular, it is common to discover asymmetrical paralysis of the abdominal, intercostal, and spinal muscles. If the intercostal muscles are paralysed on one side the vertebral bodies will tend to rotate towards that side resulting in a deformation of the rib cage (the ribs on the convex side being carried backwards to project posteriorly, whereas those on the other side are carried forward so there may be an anterior protrusion) and the presence of a hump due to the transverse processes of the vertebrae. The ribs, especially on the convex side, drop away to lie nearly vertical..$^{89}$

\section{"A very special case"}

Could we expect to find evidence that Elizabeth had any such deformities of the thorax? That would depend on their magnitude, the success of any disguise, and people's poor taste. With regard to the last, you would not expect people at that time to comment on a physical deformity in a woman but one does exist. An article in the New York Home fournal describes Mrs Browning in the 1850s as "a crooked, dried-up old woman with a horrible mouth." Mrs Kinney, who visited Mrs Browning in 1854, rushed to her defence, writing of her "beauty of spirit" but not denying that "her frame was shattered by disease." 4 But, however good the disguise, things cannot be hidden from everyone. When Mrs Browning's confinement was imminent her close friend in Florence, Mrs Ogilvy, recommended an English nurse. Mrs Browning's doctor, Sir Henry Harding, however, insisted that since her confinement was "a very special case" a particular nurse of his own recommending be engaged.

I was thankful, wrote Mrs Ogilvy, that Dr Harding had been so peremptory as Mrs Browning was by no means an ordinary patient. The old Italian nurse said to me after the birth: "E un miraculo quello bambino e venuto de quel corpo."10

If you accept the proposal that Miss Barrett's illness resulted in paralytic scoliosis with thoracic involvement her subsequent fragile health culminating in her second illness in 1837 is easily explained. Both the volume of the thorax and the functional size of the lungs are much diminished when there is any appreciable distortion of the rib cage and displacement of the thoracic spine. The lungs are smaller, less compliant and elastic, and with greater resistance to blood flow, leading to pulmonary hypertension in exercise. In addition, both the mechanical work of breathing and the oxygen cost of breathing are high because of the raised elastic resistance of the lungs and the mechanical disadvantage of the respiratory muscles, so that as ventilation increases the oxygen cost per unit of ventilation rises much faster than in normal subjects. The breathing pattern is typically rapid and shallow. As a consequence, even in health, these subjects are close to a "threshold condition," having little reserve. ${ }^{811}$ Three circumstances threaten to push these subjects beyond that respiratory threshold: exertion, chest infections, and emotional states. Although probably not more prone to chest infections than the average person, they are much more severely affected by them, and airway obstruction, as in bronchitis, may

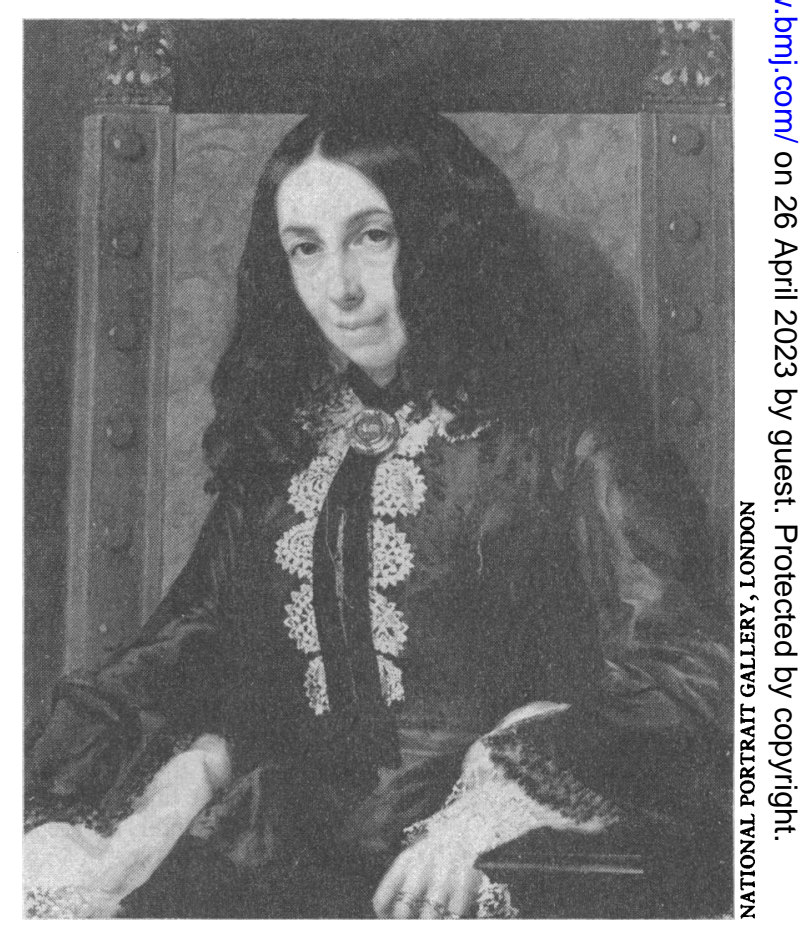

FIG 2-Elizabeth Barrett Browning by Michele Gordigiani, 1859 
produce respiratory failure. Eventually the tendency to hypoventilation, hypoxaemia, and hypercapnia lead to resting pulmonary hypertension, right ventricular hypertrophy, and, finally, cor pulmonale.

During the years 1823-37 the most important symptom of Elizabeth's delicate health was chronic fatigue. Her diary for $1831-2^{12}$ and her letters of that period to H S Boyd' show that, though moderately active, she repeatedly complained of fatigue, especially after slightly greater exertion than usual, and resented others not appreciating how exhausted she claimed to be. In fact, after too much exertion or if agitated or upset, she would collapse or even faint. These admissions have served to support the assertion that she chose, consciously or not, to retreat into illness because of social, sexual, or intellectual frustration. This in turn makes the diagnosis of malingering to account for her otherwise seemingly interminable illness of 1837-46 seem much more plausible. This may well have been the evolution of opinion among some of her family, for she wrote to her brother George from Torquay (June 1840):

In the meantime deduct from your fancies about me that I am dying in bed, from fear of the exertion of getting up . . . it isn't altogether as agreeable to lie here in the dark as you might possibly fancy.

And that others in the family continued to hold that view is evident from the vicious attack on her by her niece Arabella in $1938 . .^{6}$ There is, however, no need to invoke malingering and its unpleasant undertones; Elizabeth's fatigue was real and there is a sound physical explanation.

In the autumn of 1837 after two years in London Miss Barrett caught a cold and developed a cough, which turned into chronic bronchitis. This lasted until 1846. She had had several bad colds before, including one in London, but the lingering coughs had eventually cleared up. What made this cold so different? Was it just a cold?

\section{More than just a cold}

In a letter to Miss Mitford (29 November, 1837) she writes:

I am not so [well] myself. I caught a cold nearly two months [ago] which turned into a cough and has kept me to the house ever since and in a very weak state.

In fact, it was to keep her to the house until the following spring. Elsewhere she states that her illness began with a broken blood vessel and that it was caused by neglecting one of her coughs. Dr W F Chambers, the Queen's physician, was called in and he was to remain Elizabeth's London doctor until September 1846. But though the rupture apparently healed he was unable to cure her persistent cough. ${ }^{7}$ This must have been in November $1837,{ }^{13}$ for she continues in the same letter to Miss Mitford:

And Dr Chambers whom I was kindly persecuted into seeing yesterday ( $\mathrm{I}$ have an abhorrence of medical advice, but my sisters were obdurate) says that I must not think of stirring into the air for weeks to come. He assures me that there is no disease-only an excitability and irritability of the chest, which requires precaution.

Miss Mitford corroborates this dating of the haemorrhage in Recollections of a Literary Life:

She broke a blood vessel upon the lungs, which did not heal. ... And after attending het above a twelve month at her father's house in Wimpole Street, Dr Chambers, on the approach of winter, ordered her to a milder climate [Torquay in September 1838]. ${ }^{10}$

The ruptured vessel was very likely not in the lungs but in the nose, or possibly the throat or mouth. We read in another letter to Miss Mitford (31 December 1843) referring to a period much earlier than 1843 :

Dr Chambers on failing to stop the bleeding in my case with the common specific of lead, recommended me to a quack medicine which had been successful, he said - "Don't mention my name... but get the styptic at such a place!"

This clearly implies manual application to an accessible surface.

A cold that leads within a few weeks to a cough bad enough to cause a haemorrhage but with surprisingly few chest signs and that eventually gives rise to chronic bronchitis, suggests pertussis, a disease endemic in Victorian London. It is quite possible that Elizabeth had never been exposed to whooping cough, living to the age of 26 on an estate in Herefordshire and never having attended school. As is well known the first stage of the disease is easily mistaken for a bad cold, with the short dry cough only paroxysmal after 10 to 14 days. Since the whoop is usually absent in adults the infection would not have been identified. The straining cough causes venous engorgement of the face and throat; and epistaxis, bleeding from the mouth and throat, and blood streaked sputum may occur. The characteristic cough may persist for weeks or months and even return after a year or more. The complication of secondary bronchitis might well be expected in someone with compromised pulmonary function.

Elizabeth's long illness in Torquay (1838-41) was punctuated by dormant periods when she was able to get up from her bed and even to go out. Then the cold, the damp, or the smoky air of winter would cause her bronchitis to flare up again with fever, tachycardia spitting blood (probably bloody sputum), headache, insomnia, general exhaustion, and fainting. She also had two serious relapses in 1840 on the deaths of her brothers Samuel and Edward.

\section{Warm climate recommended}

Just as Elizabeth has been unjustly accused by some of malingering and of being a drug addict, so her doctors have been unfairly charged with incompetence. Dr Chambers, in particular, seems to have had an understanding of the disease that has not been appreciated. In his opinion it was not the lungs that were diseased' but rather the "too great fullness of the blood vessels upon them" (in 1838) 5 and the weakness of "the muscular system covering the lungs" and "the vascular system of the lungs" (in 1845). ${ }^{5}$ He reduced the tachycardia with digitalis and prescribed opium to relieve the severe coughing. As early as 1838 he was recommending a warm climate as the surest treatment ${ }^{7}$ and he was doing so again in $1845 .{ }^{3}$ After her return to London in 1841 her condition steadily improved. This was only because Elizabeth remained in a "sealed," airless bedroom for months on end, moving only between her bed and her sofa. It was a regimen that has been generally condemned and Dr Chambers has been criticised for approving it. Nevertheless, it did serve to protect her from the cold, the damp, and, most importantly, the smoke polluted air of London. $\mathrm{As} \mathrm{Mr}$ Barrett would not allow his daughter to live in Italy it was the only way to interrupt the chronic bronchitis for long enough to restore her strength.

During these years, isolated on the second floor of her father's Wimpole Street house, she took full advantage of her increasing strength and worked assiduously, writing poetry, letters, and articles and reading avidly. Many have assumed that the improvement in her health that enabled her to go out regularly in the summer of 1846 , marry, and travel to Italy was due entirely to the influence of Robert Browning, who first visited her in May 1845. In fact, the gradual improvement began in the winter of 1841-2 "Think 
of my walking to the sofa now! Isn't that an improvement?") and each summer found her better, and each winter less ill than formerly. ${ }^{5}$ Finally, with her marriage in September 1846 she escaped to a warmer climate with a less polluted atmosphere and her bronchitis did not trouble her for some years.

One legacy of Elizabeth's illness remained: her so called addiction to opium. It was prescribed by her doctors for her cough and insomnia. She never became an addict and was able to control her dependence-for example, abstaining during her pregnancies. Her own estimates of her opium consumption may well have been greatly exaggerated, for later in Italy her small son drank her recently purchased supply of special elixir and suffered no effects.

\section{Setbacks in London and Paris}

After her marriage Elizabeth's health continued to improve and despite a serious miscarriage in 1850 she was able to climb the steps to the top of Milan Cathedral in the spring of 1851. But her summer in London that year started her cough again, and succeeding visits in 1852, 1855, and 1856 each made their inroads as did the winters in Paris in 1851 and 1855 . Her bronchial attacks returned and by 1857 she was an invalid again. In paralytic scoliosis respiratory and cardiac failures usually do not appear until the fourth or fifth decade. That they did not appear in Mrs
Browning until the sixth decade would imply a less severe deformity. Once failure has become manifest the clinical course is usually rapidly downhill, characterised by repeated episodes of cardiac failure, often precipitated by pulmonary infection. ${ }^{14}$ For Mrs Browning it was a remorseless decline to her death in June 1861 from heart failure following congestion of the right lung.

1 Barrett E, McCarthy BP, ed. Elizabeth Barrett to Mr Boyd. The unpublished letters of Elizabeth Barrett Browning to Hugh Stuart Bovd. London: John Murray, 1955.

2 Ritchie A. Elizabeth Barrett Browning. In: The dictionary of national hiograph (up to 1900). Vol 3. Oxford: Oxford University Press, 1921:78-82.

3 Landis P, Freeman R, eds. The letters of the Brownings to George Barret Appendix 2. Illinois: University of Illinois Press, 1958.

Ward M. Robert Browning and his world: the private face $(1812-1861)$. London: Cassell and Co, 1968

5 Barrett E. In: Miller B, ed. Elizabeth Barrett to Miss Mitford. The unpublished letters. London: John Murray, 1954.

6 Moulton-Barrett A. The Barretts of Wimpole Street. Jamaica Daily (Gleaner. 1938 June 13.

Hewlett D. Elizabeth Barrett Browning. London: Cassell and Co, 1953.

8 Roaf R. Scoliosis. Edinburgh: Livingstone, 1966.

9 James JIP, Zorab PA, Wynne-Davies R. Paralytic scoliosis. In: Scoliosis. 2nd ed. London: Churchill Livingstone, 1976.

10 Heydon PN, Kelley P, eds. Elizabeth Barretl Browning letters to Mrs Ogilyy aith recollections by Mrs Ogilvy. London: John Murray, 1974.

11 Shneerson JM. Deformities of the thoracic cage. In: Emerson P, ed. Thoraci medicine. London: Butterworth and Co. 1981:358-65.

12 Barrett E. In: Bevridge E, ed. The Barretts at Hope End. (The early diary of Elizabeth Barrett Browning). London: John Murray, 1974.

13 Hayter A. Mrs Browning: A poet's work and its setting. London: Faber and Faber, 1962.

14 Fraser RG, Paré JAP. Diseases of the diaphragm and chest wall. In: Diagnosis of diseases of the chest. Vol 3. 2nd ed. Philadelphia: W B Saunders Co. 1979:1899-902.
Renal Unit, St Thomas's Hospital, London SE1 7EH N T Richards, MRCP, honorary registrar in nephrology

M McCann, SRN, sister

A Samson, SRN, sister

A Johnson, chief technician

Renal Unit, St

Bartholomew's Hospital, London EC1

J Tattersall, MRCP, honorary registrar in nephrology

T Mathias, SRN, sister

Correspondence to: $\mathrm{Dr}$ Richards.

BrMed f 1989;298:443-5

\title{
Dialysis for acute renal failure due to crush injuries after the Armenian earthquake
}

\author{
N T Richards, J Tattersall, M McCann, A Samson, T Mathias, A Johnson
}

On 7 December 1988 an earthquake measuring more than 9 on the Richter scale struck northern Armenia, killing thousands of people and injuring many more. The exact number killed will never be known, but official estimates range between 26000 and 50000 and local estimates between 120000 and 190000 . In the first few days after the disaster it became apparent that many people were developing acute renal failure secondary to the crush syndrome.

\section{Acute renal failure due to the crush syndrome}

Acute renal failure induced by myoglobin after trauma (the crush syndrome) was first described by Bywaters and Beall ${ }^{1}$ and Beall $e t a l^{2}$ in patients with injuries related to war. Since then there have been reports of the condition during wars ${ }^{3}$ and after earthquakes. ${ }^{4}$ Non-traumatic acute renal failure induced by myoglobin is also well documented in conditions such as drug abuse (heroin and barbiturates), alcoholism, and polymyositis. ${ }^{5}$ The condition is characterised by oliguric acute renal failure of rapid onset. The main biochemical abnormalities are severe hyperkalaemia and hyperphosphataemia with associated severe hypocalcaemia. Muscle enzyme levels are extremely high and free myoglobin is present in urine and plasma. Patients die of hyperkalaemia unless they are treated rapidly.

Treatment of the condition after a natural disaster such as an earthquake poses particular problems. Firstly, because of the difficulties in finding and extracting the victims many of them will die of hyperkalaemia before they can be treated. Secondly, all patients develop acute renal failure at the same time, thus overwhelming the available services.

\section{Appropriate aid}

Negotiations among the British government, the Royal Air Force mobile dialysis team, and officials from the Soviet Embassy failed to produce an agreeable formula for an official aid package. In general, the Soviet officials seemed to want equipment alone rather than equipment and staff combined. Several renal units in Britain offered help in providing dialysis machines and staff. The portable Redy (Sorb system) seemed the most appropriate equipment to take as it operates with small volumes of unprepared water. ${ }^{6}$ Peritoneal dialysis and continuous haemofiltration were considered but rejected because of the large amounts of sterile replacement fluid required by both. The renal unit at St Thomas's Hospital is particularly experienced in using the Redy because of the requirement to have an emergency plan in case of flooding from the Thames.

The initiative from St Thomas's and St Bartholomew's Hospitals was organised through Aid Armenia, the official relief charity. The team, consisting of a doctor, two nurses, and a technician from St Thomas's and a doctor and a nurse from St Bartholomew's was assembled on the Monday morning with equipment sufficient for 100 dialyses. Dialysis machines provided by several units, including those at Derriford Hospital, Plymouth, Bristol Royal Infirmary, and Addenbrooke's, St Helier, and St Bartholomew's Hospitals, were flown out by Soviet cargo plane on the Monday 